\title{
Project-based Learning to Enhance Pre-service Teachers' Teaching Skills in Science Education
}

\author{
Tahani Salman Alrajeh \\ College of Education, Imam Abdulrahman Bin Faisal University, Dammam, Saudi Arabia
}

Received October 16, 2020; Revised December 31, 2020; Accepted January 20, 2021

\begin{abstract}
Cite This Paper in the following Citation Styles
(a): [1] Tahani Salman Alrajeh, "Project-based Learning to Enhance Pre-service Teachers' Teaching Skills in Science Education," Universal Journal of Educational Research, Vol. 9, No. 2, pp. 271 - 279, 2021. DOI: 10.13189/ujer.2021.090202.
\end{abstract}

(b): Tahani Salman Alrajeh (2021). Project-based Learning to Enhance Pre-service Teachers' Teaching Skills in Science Education. Universal Journal of Educational Research, 9(2), 271 - 279. DOI: 10.13189/ujer.2021.090202.

Copyright $\bigcirc 2021$ by authors, all rights reserved. Authors agree that this article remains permanently open access under the terms of the Creative Commons Attribution License 4.0 International License

\begin{abstract}
Project- based learning (PBL) is a constructivist approach to learning which has been used successfully in a variety of settings and has received recognition as a method of enabling students to acquire 21st century skills (Cyprian, 2014: \& Al- Ali, 2015). Some (Al-Saifi, 2016; Taskin-Can, 2011; \& Baysura et al., 2016) have argued that if pre-service teachers are to be effective at implementing PBL with their students, they need repeated experiential exposure to the model in their university teacher training programs. One area of investigation has focused on the ability of pre-service teachers to implement the PBL model within their own classroom instructional experiences despite demonstrating adequate knowledge about PBL in their university coursework. The purpose of this manuscript is to address the value of preparing pre-service teachers to be K-12 science teachers through immersing them in PBL methodology in order to enhance their future teaching practices by modeling PBL teaching methodology in their university courses. It also sheds the light on online implementation of PBL and technology integration. 45 relevant studies have been reviewed in this manuscript. The challenges of implementing PBL found in the literature were mainly related to four: programs' policy, professional development, environment, and students' willingness. Professional development sessions for faculty members, partnerships with local and international organizations specialists in this area of learning, and continuous evaluation of the current programs can be helpful strategies in achieving successful implementation of PBL in teacher preparation programs. Implementing
\end{abstract}

PBL in teacher preparation programs contributes in fully integrating theory and practice; and positively influences student teachers' professional, academic and personal skills.

Keywords Teacher Education, Pre-service Teachers, Learner-centered Approach, Project-based Learning

\section{Introduction}

Dewey (1916) wrote "Give the pupils something to do, not something to learn; and the doing is of such a nature as to demand thinking; learning naturally results" (p. 191). Dewey has suggested that students learn through experiences. Learning occurs when teachers consider students' needs and interests, and spend time thinking of how to meet them (Al-Ali, 2015). This philosophy applies to all students from $\mathrm{K}-12$ through higher education. Educators have investigated teaching methods that enable students to learn and help impact learning so it is for the long term (Al-Ali, 2015). Al-Saifi (2016) reported Project Based Learning (PBL) methodology showed its effectiveness in educational settings in terms of developing higher-level thinking skills. This paper illustrates the importance of implementing PBL in teacher preparation programs to influence pre-service science teachers teaching skills.

PBL is a teaching methodology engaging students in the learning process and encouraging their curiosity to 
investigate meaningful and relevant real-world questions or problems (Krajcik \& Czerniak, 2018). PBL as a learning model, is based on organizing the learning process by centering learning activities within projects that challenge students to solve authentic concerns by the way of investigation and problem-solving (Al-Ali, 2015). Cyprian (2014) defined 21st century skills as the ability of an individual to think in an innovative manner. PBL prepares students with academic competency enabling them to work in collaboration with others, hence empowering them to be global citizens able of taking responsibility for their lives. The end result is the students are molded into individuals who are economically and socially successful in the current stage of globalization.

Cyprian (2014) insisted students should be exposed to PBL to enable them to become successful in the rapidly changing world of globalization. That is, it facilitates the acquisition of information literacy, lifelong learning, collaboration, and critical thinking skills. For example, in one study, standardized tests were given to both students who had been immersed in a traditional environment and those who experienced an instructional environment designed for students to learn through project applications. The results showed that while students scored similarly in the first assessment, when students were provided the same assessment one year later students who had learned the material in traditional instructional environments recalled $15 \%$ of the information tested while students who learned the material through PBL were able to recall $70 \%$ of the skills and knowledge (Cyprian, 2014).

PBL utilizes the constructivist approach to instruction to help create a learning environment for students to work actively and collaboratively in addition to promoting higher thinking skills, such as critical thinking and problem-solving (English, 2013). Grossman et al. (2019) studied the effect of PBL by surveying and interviewing accomplished PBL practitioners. They found that the practitioners sought to promote deep multidisciplinary learning, engage learners in authentic work, enhance collaboration among learners, and build an iterative culture where learners always prototype, reflect, redesign, revise, and evaluate, which are considered the core practices of PBL.

In addition to the benefits of PBL on professional side of student teachers, it has some positive effects on their personal and academic skills. Kilinic (2010) reported student teachers majoring in elementary science education reflected positive attitudes and behaviors about environmental protection after interventions based on environmental education PBL. Pepper (2013) conducted an intervention based on PBL for elementary science education with student teachers and found significant increases in their confidence in teaching science investigation skills. Tsybulsky and Muchnik-Rozanov (2019) investigated pre-service teachers' experience during their practicum course using PBL. They found that PBL helped in shaping pre-service teachers' professional identity including self-confidence and professional growth and gaining meaningful experience in terms of overcoming challenges and collaborating with their peers. These skills play role in keeping pre-service teachers motivated in their teaching practices. Zembat et al. (2020) found a significant positive relationship between the level of self-leadership skills pre-service teachers have and their motivation to teach. Torres et al. (2019) stated that using PBL with undergraduate students enhances the ownership of learning for students and motivates them to learn effectively and refines their research, management, and social skills. Mahasneh and Alwan (2018) found significant differences in self-efficacy and achievement scores of pre-service teachers who experienced PBL compared with the control group who did not experience PBL. Based on this finding, the researchers suggested the adoption of PBL in teaching pre-service teachers and confirmed the need to conduct additional research verifying the effect of PBL in Arab countries.

On the other hand, faculty members teaching pre-service teachers perceive and implement PBL differently. Lee, Blackwell, Drake, and Maron (2014) interviewed faculty members from various disciplines to investigate their definitions, implications of PBL and the challenges they encounter. The findings revealed the faculty's understanding of PBL drives their implementations. Participants confirmed the benefits of PBL professional development sessions on their own practices. However, they expressed that finding a community partner, identifying a project that fits students' needs, making students work effectively in a group work, and the difficulty of evaluating projects as challenges of implementing PBL in higher education. In Lee, Blackwell, Drake, and Maron's study (2014), they provided multiple studies showing the effectiveness of implementing PBL in particular college courses, such as engineering and technology; however, they confirmed the need for further research in details about adopting PBL in higher education in different disciplines (Lee et al., 2014).

Lortie (1975) pointed out that teachers are likely to teach in a way they were themselves taught as learners. Therefore, to promote learning, adult learners are treated as young learners in many aspects such as strategies, methods, approaches and techniques (Addae, 2016). Addae (2016) suggested that "Adult learners require learning environments, which promote their active involvement in the entire teaching and learning encounter. By encouraging dialogue, reflection, and learner autonomy in the classroom, the educator is able to help adult learners to construct meaning from a wide variety of events or information presented to them" (p.192). The manuscript examined the following research questions: (a) To what extend does PBL achieve the combination between theory and practice? (b) How is PBL different from other related instructions? (c) Is PBL appropriate for remote learning? 


\section{The Combination between Theory and Practice}

Developing educational materials is a capital-intensive venture that requires sound financial practices; therefore, many educational institutions offering teacher preparation programs tend to use locally available materials to create those materials (Chappuis, 2015). However, most of the learning materials are theory-based and lack the practical aspect of teaching (Chappuis, 2015). Practical teacher preparation programs would involve the application of the relevant materials and other educational media in transferring knowledge to the learners (König, Ligtvoet, Klemenz, \& Rothland, 2017). Therefore, the development of the practical teacher educational values is based on the psychomotor elements that improve learning far better than just reading and comprehension of theoretical materials (Ramnarain, 2018).

Teachers who rely upon theoretical elements may not have confidence to teach practical teacher preparation programs to their students even when the materials are available (Whitford, Zhang, \& Katsiyannis, 2018). However, a multidimensional approach gives the pre-service teachers the opportunity to grasp dynamic knowledge appropriate for comprehensive education (Sumrall et al., 2017).

\subsection{The Value of Combining Theory and Practice}

Mayer et al. (2017); Shih et al. (2020) confirmed the importance of integration between theory and practice in teacher education. "The separation of theory and practice is arguably the biggest issue at the heart of all reforms into initial teacher education" (Kaur, 2012; as cited in Mayer et al., 2017, p.79). Even though there are practicum courses in all teacher education programs, Mayer et al. (2017) reported many faculty and students consider taking university-based courses and practicing teaching in a variety of schools through practicum course are theory-practice divided. Embedding the professional experience into university courses is needed so theory and practice can be fully incorporated. Hollins (2015) described the teacher education programs preparing pre-service teachers in a way that enables them to be capable of combining theory and practice are programs creating powerful environments for future teachers.

Darling- Hammond (2016) introduced Bank Street College as a unique model of an institution preparing graduate pre-service teachers and assessing its students descriptively (without letter grades). This college focuses on learning through experience and the faculty and students work together learning the theoretical and implementing the practical. They provide authentic works for their environment and for society (Darling- Hammond, 2016). Horng, Zheng, Lit and Darling- Hammond (2015) conducted a study to examine the effectiveness and the influence of Bank Street teacher preparation programs on its graduates in comparison to other teacher preparation programs in New York State. They found Bank Street College is $99 \%$ characterized on student-centered approach and is $95 \%$ committed to social justice and progressive education verses $61 \%$ of other programs. The satisfaction level with preparation among Bank Street graduates was $87 \%$ while $66 \%$ was the level of satisfaction with preparation from other programs. Bank Street College enables its students to engage in a meaningful coursework and requires assignments that connect between theory and practice.

Bank Street students spend over 720 hours on teaching which assist them to gain rich teaching experience, be mentored individually and receive a constructive feedback from their supervisors. At the end of their long clinical experience, Bank Street students can relate the learning content to the real world, develop curriculum based on students' interests, needs and abilities, and create a diverse classroom environment that enhances social and emotional growth development. Overall, the study found a significant difference among Bank Street graduates as professional teachers in comparison to teachers who graduated from other teacher preparation programs in New York State (Horng et al., 2015).

Doruk (2014) indicated a learner-centered approach enhances students' educational accomplishment. The learner-centered instruction focuses on skills and practice to promote independent and critical problem solving as well as lifelong learning (Doruk, 2014). Combining theory and practice allows teachers to design instructional approaches to address unique learning interests, needs, aspirations, and cultural backgrounds of the individual students or group of learners (Morosan, Dawson, \& Whalen, 2017).

Hollins (2015) indicated after multiple studies on improving teacher preparation programs, the importance of enabling pre-service teachers to inquire, observe, research, gather information, interact within groups when they learn how to teach showed effectiveness in learning outcomes. Jacka (2015) reported developing learning processes based on learner-centered curriculum of integrating technology into teacher preparation programs in universities is needed because using technology is considered one of the challenges for pre-service teachers when they become teachers. Therefore, this practice would enable them to be capable to apply technology in their future classrooms (Jacka, 2015).

Jacka (2015) indicated most educational research emphasized the importance of changing the learning process in teacher education programs by utilizing what has been introduced in theory to influence pre-service teachers' future teaching practice (Jacka, 2015). New teachers need to be equipped with essential research-based skills that will allow them to design proper and relevant programs to make teaching easier (Vaughan, Baxley \& Kervin, 2017). However, Morosan et al. (2017) suggested that although combination of theory and practice is required in enhancing pre-service teachers' learning and understanding capacity, teachers should be cautious to avoid laxity in teaching. 
Therefore, teachers who have been well trained can determine when to use theoretical concepts and when to use practical concepts in a way that would create balanced learning for the students (Casey \& Childs, 2017).

Darling- Hammond (2016) clarified offering theory and practice separately in the learning process is considered a main issue for pre-service teachers when they are asked to practice teaching in classrooms, so they should learn how to think and act at the same time. Thus, designing instructional programs combining both theory and practice to enhance the success of teachers once they start teaching and operating within the school and societal setting is needed (Darling- Hammond, 2016). Hollins (2015) reported even though pre-service teachers take university courses to enhance their knowledge about the importance of facilitating learning and providing appropriate learning environments, based on a long term of observations, pre-service teachers were unable to demonstrate their knowledge and teaching skills in the practicum course. The results of Hollins' study suggested the learning of pre-service teachers needs treatment, and this can be done through applying modern teaching tools across teacher preparation programs (Hollins, 2015). Over the last decade, some teacher preparation programs have moved toward using constructivist-based learning to improve the quality of teaching by understanding the psychology of learners and how to influence pre-service teachers' beliefs and teaching practice (Dangel, 2011).

\section{The Differences between PBL and Other Related Instructions}

Lee, Blackwell, Drake, and Maron (2014) and Hovey and Ferguson (2014) confirmed that the faculty's understanding of PBL drives their implementations. There are some learner-centered approaches such as Problem based learning (PrBL) or doing a project as an activity could create confusion in distinguishing between them and PBL.

\subsection{PBL vs. Doing a Project}

According to the handbook published by Buck Institute of Education, the differences between PBL and doing a project are demonstrated. Doing a project comes as an activity or a project alongside the unit or at the end of the course while the project in PBL is integrated in the learning process. Learners do a project based on teacher' directions; however, they drive the project based on their inquiry in PBL. PBL is aligned to academic standards unlike doing a project. In PBL, learners collaborate in-class on organizing content and building an applicable project to the real world, then publicly share and present the results. However, doing a project can be completed alone and the end results of the project are presented in the classroom.

\subsection{PBL vs. PrBL}

Donnelly and Fitzmaurice (2005) and Harris (2015) identified the differences between PBL and PrBl. PrBL starts with a problem in a scenario format or case study. Learners in PrBL are given a problem, then they solve the problem through investigating previous knowledge and identifying areas that need more information. However, PBL is a multidisciplinary approach in which learners produce a product or an artifact through processes that require students to create their own driving question and collaboratively learn specific content knowledge and skills.

\section{The Types of Knowledge in PBL}

Conceptual, factual, metacognition and procedural knowledge are considered the main types of knowledge that educators should include while constructing curriculum or teaching utilizing PBL methodology.

\subsection{Conceptual and Factual Knowledge}

Morgan et al. (2013) wrote teachers should balance between the conceptual and factual knowledge in teaching to make the learning understandable and meaningful. The conceptual knowledge focuses on the abilities in planning, observing, developing the arguments and justifications, and the connection between concepts and ideas from different disciplines. The factual knowledge is about teaching and learning those skills (Anderson et al., 2001). Having a large content of disconnected facts is not adequate; therefore, students should be enabled to integrate the factual knowledge with the conceptual knowledge to gain usable knowledge (Morgan et al., 2013). Wallace and Husid (2017) explained the conceptual and factual knowledge involves using a conceptual change model to enhance the individual understanding of students. Furthermore, it entails concept maps through which students use previously held conceptual framework and knowledge visually (Capraro et al., 2016).

\subsection{Metacognition}

Morgan et al. (2013) emphasized the metacognitive process has to be activated in teaching. Metacognition makes students aware of their learning process, capable of evaluating if they need to understand what they received or need more information, and enables them to reflect upon their own thinking (Anderson et al., 2001). Anderson et al. (2001) referred to three types of metacognitive knowledge as: strategic knowledge, which provides students with multiple strategies for learning; knowledge of cognitive tasks, which refers to understanding the differences among cognitive tasks; and self-knowledge, which allows students to determine their own strengths and weaknesses in learning. A student with strong metacognitive knowledge will be able 
to determine the quality of his or her work and evaluate whether the information he or she has gathered is good enough to support a claim or if more searching is needed (Krajcik \& Czerniak, 2018).

\subsection{Procedural Knowledge}

Procedural knowledge is about knowing the process of how to do something and its importance appears in practice (Anderson et al., 2001). For example, a student may know the "content" of knowledge about a tennis game but cannot play tennis because he or she does not have enough procedural knowledge to be able to play. The same thing applies to a student when he/she knows the definition of a solution but does not know how to make a solution. Procedural knowledge enables students to know how to deal with the knowledge they have by making decisions, evaluating solutions, analyzing and interpreting data. (Krajcik \& Czerniak, 2018)

\section{The Steps of PBL}

Strategies promoting self-reliance should be considered in implementing PBL because they are the essence of PBL, such as by enabling students to conduct independent investigations, write reports, keep a journal, and maintain a blog (Krajcik \& Czerniak, 2018). Morgan et al. (2013) reported implementing PBL in classrooms exposes students to solve problems derived from real world problems. Those kinds of problems called ill-structured problems enhance students' ability to develop problem solving skills that will enable them to face the challenges of the life by providing varied solutions. This means there is not just one answer. PBL is different from the problems usually included in school textbooks called well-structured problems, which do not reflect the real world and require providing a certain solution (Morgan et al., 2013, p.44). Krajcik and Czerniak (2018) specified criteria for the authentic tasks used in PBL. These criteria include driving questions to focus and sustain activities, relevance of topics or questions to students' lives outside school, and disciplinary core ideas, scientific practices, and crosscutting concepts that emerge as needed to answer a driving question. (Krajcik \& Czerniak, 2018, p. 53)

Krajcik and Czerniak (2018) outlined ten steps for developing a project plan in PBL approach. These steps can be described as pre-implementation stage. First step is that selecting performance expectations standards that are identified by school or state. Second, examining the disciplinary core ideas (DCIs) contained in the performance expectations to have a deep understanding and identify the elements associated with the performance expectation. Third, selecting the practices of subject being studied and crosscutting concepts that work with the DCIs and support instruction to build toward the DCIs. Fourth, identifying the phenomena or problems that students will experience and make sense of them throughout the unit. Fifth, developing the driving question that will guide instruction throughout the unit. Driving questions relevant to the phenomena or problem can always be modified as project planning progresses. Sixth, developing learning performances. They build over time to the level of understanding intended in the performance expectations. Seventh, developing a coherent sequence of learning tasks that link to the various performance expectations. Eighth, integrating the DCIs with other related core ideas from different disciplines. Ninth, developing corresponding lesson plans that activate strategies, materials, and experiences that help students learn the learning performance. Tenth, identifying tasks that can be used for formative and summative assessment in the unit. (Krajcik \& Czerniak, 2018, p.315).

During PBL implementation, there are mainly four phases that include launching the project, building student knowledge, developing and critiquing products and answers to the driving question and finally presenting those products to the audience of their choice. Figure 1 illustrates the four phases of the project path that help teachers consider how they want this project to be experienced by their students (Buck Institute for Education, 2020) (see Figure 1).

Morgan et al. (2013) described teaching someone PBL is like teaching them how to ride a bike. The process requires patience and takes time to be experienced in PBL's techniques. They relayed the principles of designing PBL. Making content accessible by enabling students to interact with content, extract examples, and build new ideas from prior knowledge is one of the principles of designing PBL that makes the learners more independent and refines their higher thinking skills.

Another principle is that making thinking visible by modeling scientific process, allowing students to experiment and interpret and scaffolding students to provide an opportunity for students to monitor their own learning. Helping students learn from others is considered the core component in PBL. Students with their peers in PBL discuss, argue with respect, share ideas, compare between them, and identify the connections in which they develop their social, communication, listening, and response skills. Teachers in PBL promote autonomy and lifelong learning where they encourage students in organizing the ideas, constructing the arguments, and adding new evidence. On the other hand, teachers work to scaffold students to engage all students in the learning process. (Morgan et al., pp.16-17) 


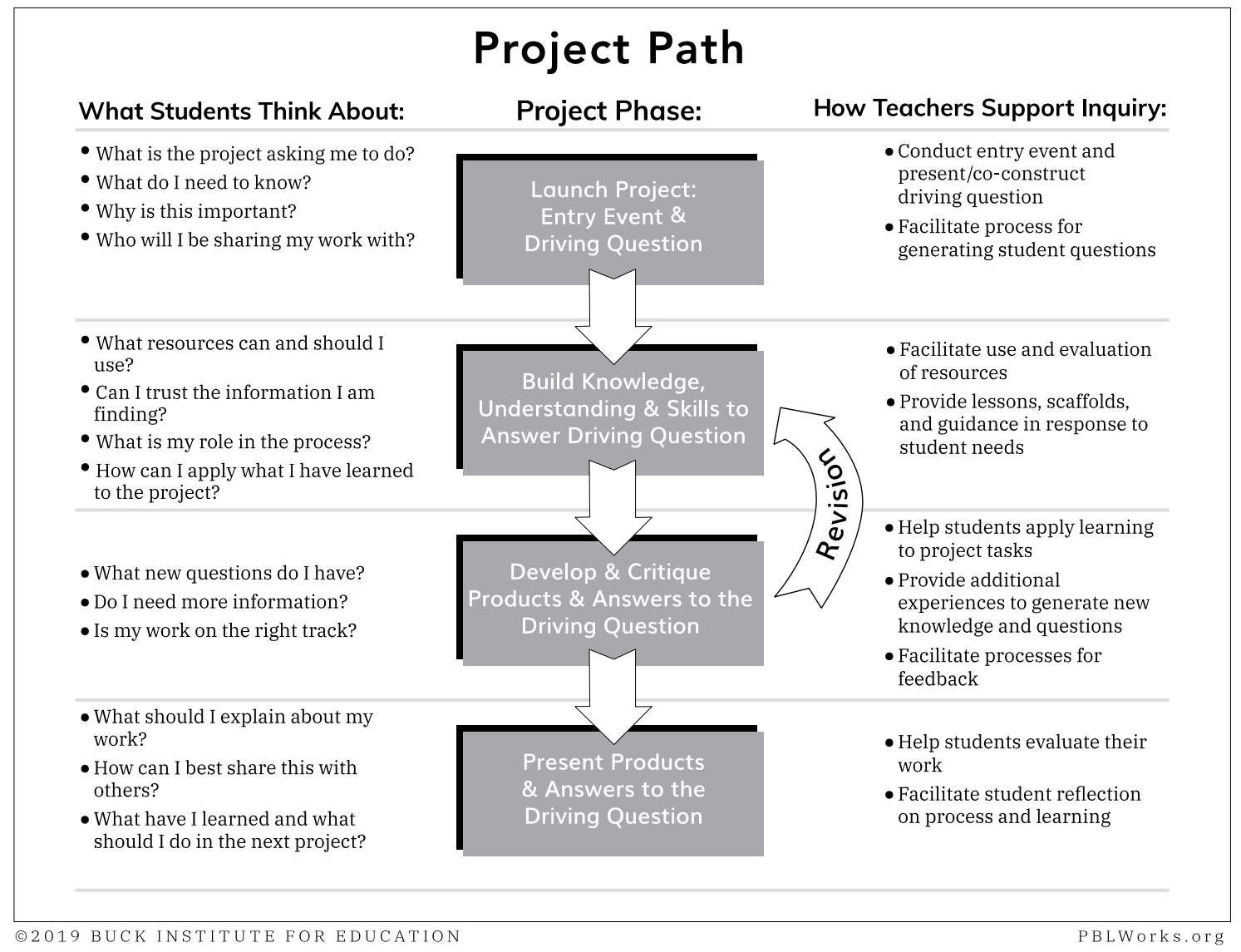

Figure 1. Project Path During Implementing PBL

\section{The Challenges of Implementing PBL}

PBL can be difficult for science teachers to adopt because it is something they have not experienced. It can be time consuming for teachers who have been taught by a traditional teaching approach, which most teacher preparation programs still apply (Morgan et al., 2013). Cyprian (2014) reported introduction of PBL curriculum may lead to the creation of substantial tensions in the initial implementation stages. Faculty may be reluctant to implement it for the fear of losing control over their school curriculum (Cyprian, 2014; Meier \& Hendel, 2019). Harris (2015) conducted a questionnaire among middle school teachers regarding the challenges of implementing PBL they perceive. He found that teachers agreed the most challenging barriers in implementing PBL are time, meeting state requirements, inclusion of the standards, designing PBL and implementing it within school timeframe. MacMath, Sivia, and Britton (2017) conducted a mixed method study on ninth grade teachers from different disciplines. They reached to detailed results regarding the benefits, challenges of implementing PBL and support needed. Some of these challenges were that students prefer to learn in a traditional way because it is easier to study the materials and then get the grade unlike
PBL which requires the ownership learning and variety of responsibilities. Teachers expressed the difficulty of using PBL on their own and confirmed the importance of adopting PBL at the whole school level, allowing more time for them, and funding from school administration as a support for successful implementation.

Hovey and Ferguson (2014) surveyed 134 pre-and in-service teachers regarding their perspectives and experience with PBL. The result revealed that even though teachers are aware of the effectiveness of PBL as teaching methodology, their understanding of PBL is not adequately clear. They believe that the purpose of PBL is to create projects and confirm the need for training for both teachers and administrators. The researchers concluded that the study used the quantitative approach which limited finding more details in the results; therefore, they recommended applying mixed methods approach in the future to get more clarifications and insights to the results. Han, Yalvac and Capraro (2015) offered professional development session to 92 teachers to investigate teachers' understanding and implementation of PBL. They recognized the effectiveness of PD sessions through teachers' communication regarding PBL concepts. However, teachers' understanding of PBL did not reflect their implementations. Teachers reported that students' willingness, subject, time and technologies as challenges 
of implementing PBL.

\section{Implementing PBL Remotely}

Due to the COVID-19 crisis and the sudden conversion of education to distance learning, PBL has shown its flexibility. PBL Works Organization certified by Buck Institute for Education (2020) has posted a variety of ways that can be used to assist educators to keep using PBL in an online learning environment and offered digital tools that facilitate the project planning, construction, evaluation, and public presentation phases. These practices in an unexpected situation show the possibility of overcoming the challenges hindering PBL implementation, such as lack of time.

As a Senior Curriculum Manager in Buck Institute for Education, Field (2020) has emphasized that connecting theories with current events is the best way to achieve authentic learning. She suggested the identification of connection points for teachers to create driving questions, such as discussing the best ways for governments to respond to COVID-19, tracking the history of pandemics and their effects, comparing COVID-19 with other infections, utilizing mathematical tools to predict the spread of the pandemic, and identifying helpful ways in preventing misinformation regarding this pandemic through communication tools (Field, 2020). The same thing can be applied to teacher preparation programs. As an example of this situation, faculty members can ask their students to discuss the most appropriate way for the Department of Education to respond to the current crises, identify the effective ways for delivering curriculum, develop a plan or unit fits to remote learning, think about ways to support social and emotional learning in the current situation, strategize against the barriers of remote learning, sympathize with students who do not have access to Internet, and find creative solutions. Subsequently, students' projects can be posted or presented in a public educational platform to widen its reach.

The current circumstance has led to the removal of some challenges faced by faculty member when implementing PBL, such as lack of time. However, the current crisis has also created other technology-related challenges, thereby confirming that understanding the models of proper integration of technology in education is a necessity for all educators. There are multiple models for integrating technology into learning process. Educators could adopt the most appropriate one in their teaching practices. Here is an example of Dr. Ruben Puentedura's model clarifying the technology integration into learning process. Puentedura (2014) has developed the SAMR model, which is a taxonomy-based model. This model guides teachers to evaluate how they integrate technology into their instructional practices. This model is composed of four levels: the bottom two levels (i.e., enhancement levels) represent the lower three levels of taxonomy model, while the higher two levels (i.e., transformation levels) represent the upper three levels of taxonomy model which are used to examine the higher thinking skills. The level of technology integration increases throughout these four levels (Puentedura, 2014).

Puentedura (2014) addressed the four levels as follows. At the substitution level, "technology acts as a direct tool substitute, with no functional change." For example, a handwritten task is converted to a Word software program. In this case, a student has substituted a handwritten task to a typed task with no change in student engagement. At the augmentation level, "technology acts as a direct tool substitute, with functional improvement." For instance, typed task can be enhanced by utilizing the program features and tools for formatting. The task in this level is the same as the previous one, but the technology augments it with enhanced productivity. At the modification level, "technology allows significant task redesign." For instance, by taking the same task, teachers can let students share their works with their peers via Google docs, which encourages students to collaborate and provide feedback to one another. The technology in this stage has significantly modified the task by the interaction and peer evaluation among students. At the redefinition level, "technology allows for the creation of a new task, previously inconceivable." At this level, students can transform their tasks to a tangible product by creating it in a movie format, interactive activity, or educational games which can be made available on a website. Then, students can publish their works on a public technology platform to receive feedback from people they are interested in. The SAMR model provides educators with various choices to decide the most appropriate one for a specific topic and assist them in planning for technology integration in their practice. Overall, multidisciplinary science is clearly emerging which demands educators to expand their major area and develop their skills upon that.

\section{Conclusions}

In the recent past, PBL has received recognition as a method of enabling students to acquire 21st century skills (English, 2013). Al-Saifi (2016) reported many studies have confirmed the existence of obstacles that affect the implementation of PBL. One area of investigation has focused on the ability of pre-service teachers to implement the PBL model within their own classroom instructional experiences despite demonstrating adequate knowledge about PBL in their university coursework. Professional development sessions for faculty members, partnerships with local and international organizations specialists in this area of learning, and continuous evaluation of the current programs can be helpful strategies in achieving 
successful implementation of PBL in teacher preparation programs. Given that PBL is a multidisciplinary approach, investigating to what extent faculty members at the college level have integrated other disciplines in their courses and the ways of collaboration among faculty in making the courses integrative is another area needed to focus on. Differentiations of PBL implementations should be questioned by conducting focus group interviews with faculty members to analyze the rationale behind and factors affecting this issue. Why they are implementing it differently? Did they organize and collaboratively decide how the course content would be delivered?

It would be helpful for future research to hear from pre-service teachers and other stakeholders to reach a more comprehensive understanding of PBL adoption in teacher preparation programs. Evaluating teacher preparation programs and redesigning the curriculum based on PBL are also helpful. Synchronous and asynchronous learning based on PBL might also be considered as major parts of the learning process which would help professors and students develop their technology-related skills. The applications of PBL through technology and distance learning are worthy of further investigation.

\section{REFERENCES}

[1] Addae, D. (2016). Promoting effective teaching and learning in adult education: a model-based approach. Turkish Journal of Education, 5 (4), pp. 184-192. doi: 10.19128/turje.26790 9.

[2] Al-Ali, E. (2015). The effect of Project based Learning strategy on developing creative thinking skills, academic achievement, attitudes toward science on third intermediate grade students in Tabuk, doctoral dissertation, Jordan University, Amman.

[3] Al-Saifi, A. (2016). Science teachers' perceptions toward using Project-based Learning in public schools in Jenin county. Palestine: Alnajah University, Master theses.

[4] Anderson, W., Karthwohl, R., Arasian, W., Cruikshank, A., Mayer, E., Pintrich, R., Raths, J., \& Wittrock, C. (2001). A taxonomy for learning, teaching, and assessing: A revision of Bloom's Taxonomy of Educational Objectives. New York: Longman.

[5] Baysura, O.D., Altun, S. \& Yucel-Toy, B. (2016). Perceptions of teacher candidates regarding project-based learning. Eurasian Journal of Educational Research, 62, 15-36. doi:10.14689/ejer.2016.62.3.

[6] Buck Institute for Education, PBL Handbook: "Doing a project" vs. Project Based Learning, Retrieved on April 8, 2020 athttps://www.pblworks.org/doing-project-vs-projectbased-learning

[7] Capraro, M., Capraro, M., Scheurich, J., Jones, M., Morgan, J., Huggins, S., \& Han, S. (2016). Impact of sustained professional development in STEM on outcome measures in a diverse urban district. Journal of Educational Research, 109(2), 181-196. doi: 10.1080/00220671.2014.936997.

[8] Casey, C.E, \& Childs, R.A. (2017). Teacher education program admission criteria and what beginning teachers need to know to be successful teachers. Canadian Journal of Educational Administration and Policy, 67, 1-24. Retrieved from

https://journalhosting.ucalgary.ca/index.php/cjeap/article/vi ew/42748

[9] Chappuis, J. (2015). Seven strategies of assessment for learning (2nd ed.). Upper Saddle River, NJ: Pearson Education.

[10] Cyprian, T. (2014). Teacher self-efficacy in a project-based learning (PBL) classroom. New York, NY: Freeman.

[11] Dangel, J.R. (2011). An Analysis of Research on Constructivist Teacher Education in Education, 17 (2). Retrieved from http://www.ineducation.ca/issue 5

[12] Darling-Hammond, L. (2016). Research on Teaching and Teacher Education and Its Influences on Policy and Practice. Educational Researcher, 83-91. doi: 10.3102/0013189X166 39597.

[13] Dewey, J. (1916). Thinking in Education. Democracy and Education: An Introduction to The Philosophy of Education (p. 191). New York: The Free Press. New York: Longman

[14] Donnelly, R. Fitzmaurice, M. (2005) Collaborative Project-based Learning and Problem-based Learning in Higher Education: a consideration of tutor and student role in learner-focused strategies. Technological University Dublin. Retrieved from https://arrow.tudublin.ie/ltcbk

[15] Doruk, B. K. (2014). The educational approaches of Turkish pre-service elementary mathematics teachers in their first teaching practices: Traditional or Constructivist? Australian Journal of Teacher Education, 39 (10). doi: 10.14221/ajte.2 $014 \mathrm{v} 39 \mathrm{n} 10.8$.

[16] English, M. (2013). The role of newly prepared PBL teachers' motivational beliefs and perceptions of school conditions in their project based learning implementation. Fairfax, VA: Guilford.

[17] Field, S. (2020, March 17). When a Current Event Project = Coronavirus.

https://www.pblworks.org/blog/when-current-event-project - coronavirus

[18] Grossman, P., Pupik Dean, G., Kavanagh, S., Herrmann, Z. (2019). Preparing teachers for project-based teaching. Phi Delta Kappan, $100(7)$, 43-48. Retrieved from https://kappanonline.org/preparing-teachers-project-based-t eaching-grossman-pupik-dean-kavanagh- herrmann/

[19] Han, S., Yalvac, B., Capraro, M. M., \& Capraro, R. M. (2015). In-service Teachers' Implementation and Understanding of STEM Project Based Learning. Eurasia Journal of Mathematics, Science \& Technology Education, 63-76. doi: 10.12973/eurasia.2015.1306a.

[20] Hollins, E. (2015). Rethinking Field Experiences in Preservice Teacher Preparation: Meeting New Challenges for Accountability. New York: Routledge.

[21] Horng, E., Zheng, X., Lit, I., \& Darling-Hammond, L. (2015). Preparation, Professional Pathways, and 
Effectiveness of Bank Street Graduates. Stanford Center for Opportunity Policy in Education (SCOPE). Retrieved from https://edpolicy.stanford.edu/sites/default/files/publications/ scope- report-preparation-professional-pathways_0.pdf

[22] Hovey, K., Ferguson, A. (2014). Teacher perspectives and experiences. Using project-based learning with exceptional and diverse students. Curriculum and Teaching Dialogue 16(1):77-90

[23] Jacka, L. (2015). Virtual worlds in pre-service teacher education: the introduction of virtual worlds in pre-service teacher education to foster innovative teaching-learning processes', PhD thesis, Southern Cross University, Lismore, NSW.

[24] Kilinic, A. (2010). Can project-based learning close the gap? Turkish student teachers and pro environmental behaviors. International Journal of Environmental \& Science Education, 5(4), 495-409. Retrieved from http://www.ijese.net/

[25] Krajcik, J., Czerniak, C. (2018). Teaching Science in Elementary and Middle School. New York: Routledge.

[26] König, J., Ligtvoet, R., Klemenz, S., Rothland, M. (2017). Effects of opportunities to learn in teacher preparation on future teachers' general pedagogical knowledge: Analyzing program characteristics and. Studies in Educational Evaluation, 122-133. doi: 10.1016/j.stueduc.2017.03.001

[27] Lee, J. S., Blackwell, S., Drake, J., \& Moran, K. A. (2014). Taking a leap of faith: Redefining teaching and learning in higher education through project-based learning. Interdisciplinary Journal of Problem-Based Learning, 8(2), 8-13. doi: 10.7771/1541-5015.1426.

[28] Lortie, D. C. (1975). Schoolteacher: A Sociological Study. Chicago, IL: University of Chicago Press.

[29] MacMath, S., Sivia, A., \& Britton, V. (2017). Teacher perceptions of project- based learning in the secondary classroom. Alberta Journal of Educational Research, 63(2), 175-192. Retrieved from https://journalhosting.ucalgary.ca/ index.php/ajer/

[30] Mahasneh, A. M., \& Alwan, A. F. (2018). The Effect of Project-Based Learning on Student Teacher Self-efficacy and Achievement. International Journal of Instruction, 11(3), 511-524. doi: 10.12973/iji.2018.11335a.

[31] Mayer, D., Dixon, M., Kline, J., Kostogriz, A., Moss, J., Rowan, L., Gibbs, B., \& White, S. (2017). Studying the Effectiveness of Teacher Education: Early Career Teachers in Diverse Settings. Singapore: Springer.

[32] Meier, R. and Hendel, A. (2019). A Project-Based Learning Unit Plan: An Inquiry into Frogs. Open Journal of Social Sciences, 7, 70-78. doi:10.4236/jss.2019.711006.

[33] Morgan, R., Capraro, M. M., \& Capraro, R. M. (2013). STEM Project-Based Learning: An Integrated Science, Technology, Engineering, and Mathematics (STEM) Approach. Rotterdam: Sense Publishers.

[34] Morosan, C., Dawson, M., \& Whalen, E. A. (2017). Using active learning activities to increase student outcomes in an information technology Course. Journal of Hospitality \& Tourism Education. 29(4), 147-157. doi:10.1080/10963758. 2017.1382369
[35] Pepper, C. (2013). Pre-service teacher perceptions of using problem based learning in science investigations. Teaching Science, 59(1), 23-27. Retrieved fromhttps://search.informi t.com.au/browseJournalTitle;res=IELHSS;issn=1 449-6313

[36] Puentedura, R. (2014). Building transformation: An introduction to the SAMR model. Retrieved from http://www.hippasus.com/rrpweblog/archives/2014/08/22/B uildingTra nsformation_AnIntroductionToSAMR.pdf

[37] Ramnarain, U. (2018). Teachers beliefs and attitudes about inquiry-based learning in a rural school district in South Africa. South African Journal of Education, 1-10. doi: 10.15700/saje.v38n1a1431.

[38] Sumrall, T., Scott-Little, C., La Paro, K., Pianta, R., Burchinal, M., Hamre, B., Downer, J., Howes, C. (2017). Student Teaching Within Early Childhood Teacher Preparation Programs: An Examination of Key Features Across 2- and 4-Year Institutions. Early Childhood Education Journal, 821-830. Retrieved from https://www.s pringer.com/journal/10643

[39] Taskin-Can, B. (2011). The Perceptions of Pre-Service Science Teachers Concerning Constructivist Perception to Teaching. Journal of Baltic Science Education, 10(4), 219-228. Retrieved fromhttp://www.scientiasocialis.lt/jbse/ $? \mathrm{q}=$ node $/ 230$

[40] Torres, A. S., Sriraman, V., \& Ortiz, A. M. (2019). Implementing project based learning pedagogy in concrete industry project management. International Journal of Construction Education and Research, 15(1), 62-79. doi: 10.1080/15578771.2017.1393475.

[41] Tsybulsky, D., \& Muchnik-Rozanov, Y. (2019). The development of student-teachers' professional identity while team-teaching science classes using a project-based learning approach: A multi-level analysis, Teaching and Teacher Education (79) 48-59. doi: 10.1016/j.tate.2018.12.006.

[42] Vaughan, M., Baxley, T, \& Kervin, C. (2017). Connecting the Dots: A Scaffolding Model for Undergraduate Research. National Forum of Applied Educational Research Journal, 1-12. Retrieved fromhttp://www.nationalforum.com/Journa ls/NFAERJ/NFAERJ.htm

[43] Wallace, V., \& Husid, W. (2017). Collaborating for inquiry-based learning: School librarians and teachers partner for student achievement. Santa Barbara, CA: Libraries Unlimited.

[44] Whitford, K., Zhang, D., \& Katsiyannis, A. (2018) Traditional vs. Alternative Teacher Preparation Programs: A Meta-Analysis. Journal of Child Family Study, 671-685. doi: 10.1007/s10826-017-0932-0.

[45] Yi-Huang Shih, Shen-Fei Chen, \& Yan-Hong Ye (2020). Taiwan's "White Paper on Teacher Education": Vision and Strategies. Universal Journal of Educational Research, 8(11), 5257-5264. DOI: 10.13189/ujer.2020.081126.

[46] Zembat, R., Arslan Ciftci, H. \& Duran, A. (2020). Analyzing the relationship between pre-service preschool teachers' self-leadership skills and motivation. Cypriot Journal of Educational Science. 15(1), 095-103. doi:10.18844/cjes.v1 5 i1.3248 